\title{
PENGEMBANGAN SOFTWARE PEMBELAJARAN MULTIMEDIA INTERAKTIF
}

Oleh: Ade Koesnandar *

\section{Abstrak}

Multimedia interaktif merupakan konvergen dari berbagai media seperti video, audio, foto, grafis, animasi, dan teks yang dikemas secara terintegrasi dan interaktif. Karena sifatnya tersebut multimedia interaktif mempunyai potensi yang sangat besar untuk digunakan dalam pembelajaran. Secara umum, langkahlangkah pembuatan multimedia pembelajaran interaktif terdiri dari; analisis kebutuhan, dilanjutkan dengan pemilihan topik, penyusunan garis besar isi, penulisan naskah, pelaksanaan produksi, evaluasi dan revisi, serta pengemasan.

Kata kunci: analisis kebutuhan, pemilihan topik, garis besar isi, peta materi, naskah, produksi, evaluasi dan revisi, serta pengemasan.

\section{PENGANTAR}

Tulisan ini disusun untuk memenuhi sejumlah permintaan dari berbagai pihak yang ingin mengetahui proses pengembangan multimedia pembelajaran interaktif. Tulisan disajikan dengan bahasa yang sederhana dan praktis agar mudah dipahami. Materi tulisan selain berdasarkan pada sejumlah buku referensi, sebagian besar adalah berdasarkan pengalaman selama lebih dari lima tahun penulis terlibat langsung dalam pengembangan software pembelajaran multimedia interaktif.

Sofware multimedia pembelajaran interaktif (MPI) adalah media pembelajaran yang merupakan kombinasi dari berbagai unsur media yang

*) Drs. Ade Koesnandar, M.Pd., adalah Kepala studio Multimedia pada Pustekkom Depdiknas 
terdiri dari teks, grafis, foto, animasi, video, dan suara yang disajikan secara interaktif. Pemanfaatan multimedia dalam pembelajaran berdasarkan asumsi bahwa proses komunikasi pembelajaran akan lebih baik apabila dapat digunakan berbagai media sesuai dengan karakteristiknya. Sejumlah penelitian membuktikan bahwa pemanfaatan multimedia dalam pembelajaran memberikan pemahaman yang lebih baik dan lebih lama bagi siswa, memberikan daya tarik, baik digunakan sebagai metode pemecahan masalah, meningkatkan kemampuan anak berfikir kritis, eksploratif, dll.

Sebagai media yang relatif baru, MPI banyak diminati, bukan hanya oleh kalangan pendidikan sebagai user produk MPI, melainkan juga para pengembang media pembelajaran. Pustekkom sebagai institusi yang bertugas dalam hal pendayagunaan teknologi informasi dan komunikasi untuk pembelajaran, juga telah mengembangkan prototipe MPI sejak tahun 1998. Seiring dengan berkembangnya teknologi komputer multimedia dan internet, maka MPI merupakan salah satu solusi dalam pembelajaran. Di antara masalah pembelajaran yang dapat teratasi dengan MPI adalah kebutuhan sumber belajar yang berkualitas dan memenuhi standard bagi guru dan siswa, pemerataan sumber belajar dan konsistensi materi pembelajaran untuk seluruh siswa yang tersebar di berbagai daerah sehingga tidak ada lagi perbedaan sumber belajar bagi sekolah di desa dan kota. Di samping itu, dengan pemanfaatan MPI pembelajaran akan lebih menarik dan menyenangkan.

\section{LANGKAH-LANGAKAH PENGEMBANGAN MM INTERAKTIF}

Pernahkah anda menyaksikan seorang arsitek membangun jembatan? Dari mana mereka mulai bekerja? Biasanya mereka bekerja mulai dengan membuat gambar rancang bangun. Gambar rancangan sangat bermanfaat untuk menjadi pedoman dalam pelaksanaan pembangunan. Demikian pula halnya pembuatan media pembelajaran sebaiknya dimulai dengan membuat rancangan. Sebagaimana seorang arsitek, sebelum membangun perlu menjawab dulu pertanyaan mengapa jembatan perlu dibangun, untuk siapa jembatan itu, dilalui kendaraan berat ataukah hanya untuk orang yang menyebrang saja? Pertanyaan-pertanyaan dasar 
tersebut berlaku umum baik bagi seorang arsitek ataupun bagi seorang pengembang media pembelajaran.

Bagaimana langkah-langkah pembuatan media pembelajaran? Secara singkat langkah-langkah tersebut dapat digambarkan sebagai berikut.

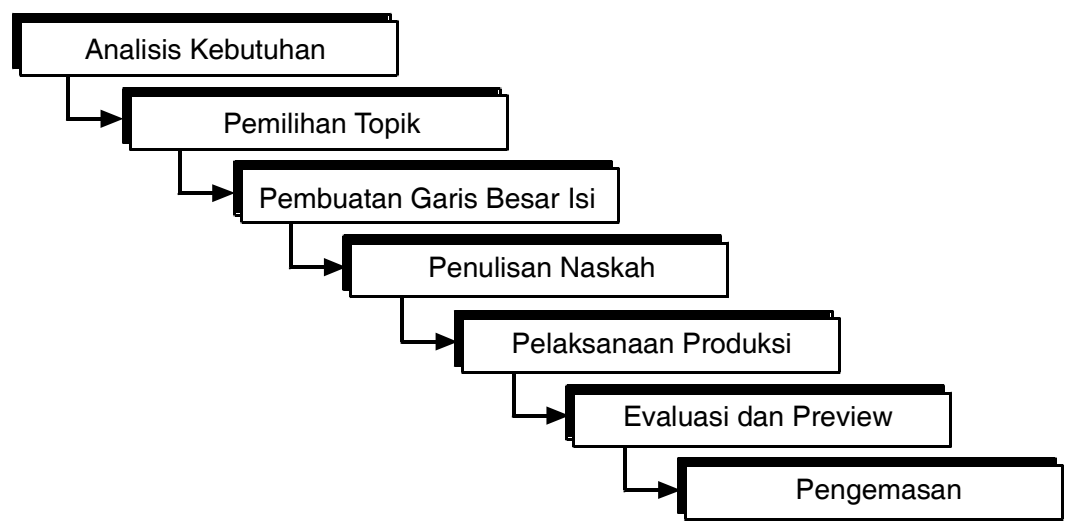

Langkah-langkah pembuatan media pembelajaran dimulai dari analisis kebutuhan, dilanjutkan dengan pemilihan topik, penyusunan garis besar isi, penulisan naskah, pelaksanaan produksi, evaluasi dan revisi, serta pengemasan.

\section{Analisis kebutuhan}

Suatu program media yang baik adalah yang dapat menjawab kebutuhan pemakainya. Oleh karena itu, pengembangan program media harus dimulai dari kebutuhan. Namun demikian, kita seringkali tidak menyadari akan adanya kebutuhan. Dari mana kita tahu ada kebutuhan? Kebutuhan biasanya diketahui dari adanya masalah. Masalah tersebut mungkin berupa rendahnya prestasi siswa, kurangnya motivasi siswa dalam belajar, kesulitan guru dalam menyampaikan materi pelajaran, kurangnya bahan belajar dsb. Namun perlu diingat bahwa tidak semua masalah dapat diatasi dengan membuat media pembelajaran. Kita perlu mengidentifikasi secara tepat, masalah-masalah apa yang solusinya adalah pembuatan media pembelajaran. 


\section{Diagram Alur Analisis Kebutuhan}

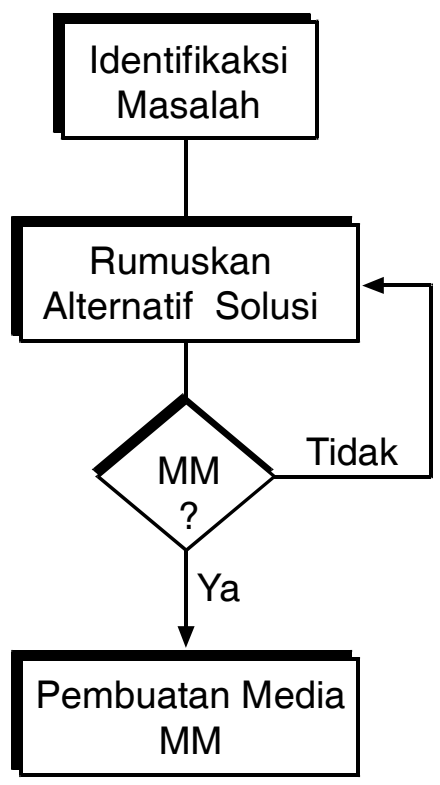

Analisis kebutuhan dapat anda lakukan dengan cara sederhana maupun menggunakan metode ilmiah. Hal tersebut akan tergantung kepada seberapa besar akurasi jawaban atas kebutuhan yang anda inginkan, dan seberapa besar resiko yang mungkin terjadi apabila keputusan telah diambil. Berikut beberapa pertanyaan yang dapat membantu anda dalam melakukan analisis kebutuhan.

Apakah ada kesulitan dalam proses belajar mengajar?

Masalah apa sajakah yang menyebabkan kesulitan tersebut?

Apakah kesulitan tersebut dapat diatasi dengan multimedia interaktif? Apakah dapat menggunakan media yang telah tersedia ataukah perlu membuat sendiri?

Apabila solusi yang tepat adalah perlu media membuat MPI, teruskan ke pembuatan media tersebut, namun apabila solusi bukan pembuatan MPI, carilah alternatif solusi lain. 


\section{Pilih topik yang tepat sesuai kebutuhan}

Apakah semua topik cocok untuk disajikan dalam media pembelajaran MPI? Pada dasarnya semua topik yang ada pada kurikulum dapat disajikan dengan menggunakan MPI. Yang terpenting bukan topik apa yang bisa dimediakan namun bagaimana penyajian topik tersebut secara sederhana, jelas, menarik, dan mudah untuk dipahami.

Namun demikian, pemilihan topik perlu dilakukan agar kita dapat menentukan prioritas topik apa yang sangat kita perlukan. Berikut beberapa langkah yang dapat menjadi pedoman.

Pertama-tama anda perlu pertimbangkan apakah topik tersebut esensial, relatif tetap dan tidak cepat berubah? Pertanyaan ini penting mengingat pembuatan media seringkali tidak mudah dan tidak murah. Apabila kita memilih topik yang tidak terlalu penting atau topik itu cepat berubah maka lebih baik anda cari topik lain.

Pertanyaan selanjutnya adalah apakah topik itu sulit? Kesulitan dapat dilihat dari beberapa sudut pandang, antara lain secara substansi materi tersebut mungkin terlalu abstrak, rumit, ataupun sesuatu yang baru dan belum dikenal oleh siswa. Kesulitan juga dapat dilihat dari pencapaian hasil belajar siswa, apakah selama ini siswa selalu mendapatkan nilai yang rendah untuk topik tersebut? Kesulitan juga dapat dilihat dari waktu, biaya, bahaya, dll. Suatu topik akan lebih jelas kalau siswa melihat atau mengalami secara langsung. Sebagai contoh peristiwa letusan gunung atau reaksi nuklir. Untuk melihat dan mengalami langsung peristiwa tersebut perlu waktu dan biaya yang mahal di samping resiko yang mungkin terjadi, maka media merupakan solusi alternatif. 


\section{Diagram Alur Pemilihan Topik}

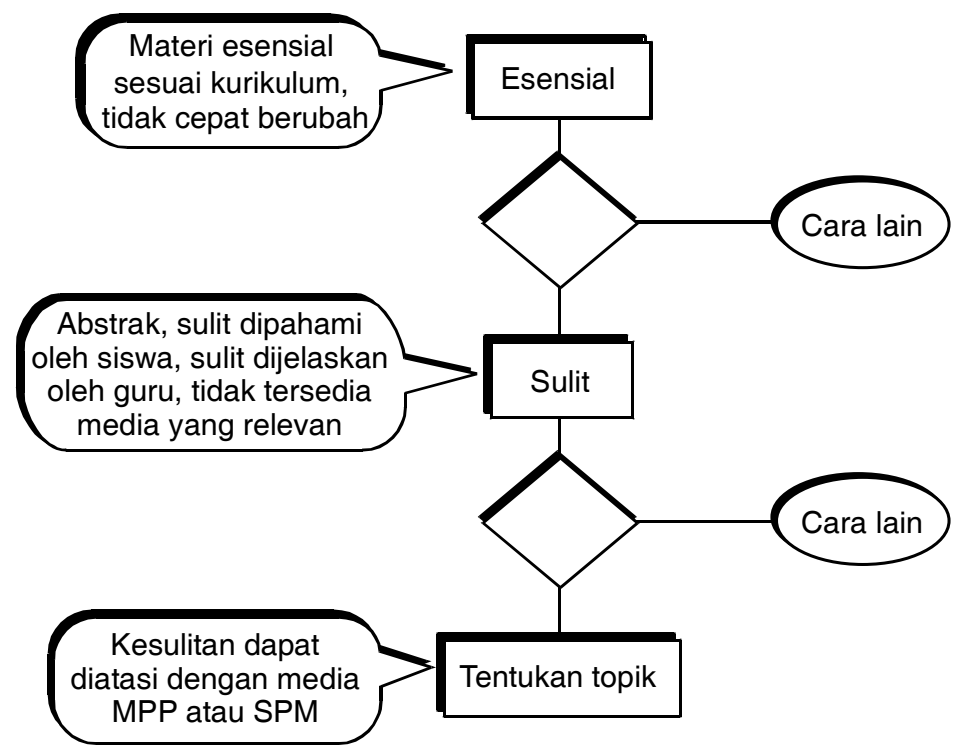

Berdasarkan jawaban atas pertanyaan-pertanyaan di atas anda dapat menentukan prioritas topik yang akan anda kembangkan menjadi media pembelajaran.

\section{Buatlah garis besar isi media}

Langkah selanjutnya adalah mulai membuat rancangan. Rancangan media pembelajaran tidak berbeda dengan rancangan pelajaran yang biasa anda lakukan sehari-hari sebagai persiapan mengajar. Rancangan berisi tujuan, sasaran, strategi, materi, media, dan evaluasi. Rancangan dapat pula anda tuangkan dalam format garis besar isi media atau sering disebut GBIM. Untuk membuata GBIM yang baik, anda dapat lakukan terlebih dahulu dengan membuat peta materi untuk topik yang telah anda pilih. Peta materi adalah gambar skema yang dibuat untuk menunjukkan rincian dan hubungan antar bagian materi yang tercakup dalam besaran materi tertentu. Misalnya, topik yang anda pilih adalah otomotif (mobil), maka anda buat peta materi tentang mobil. 


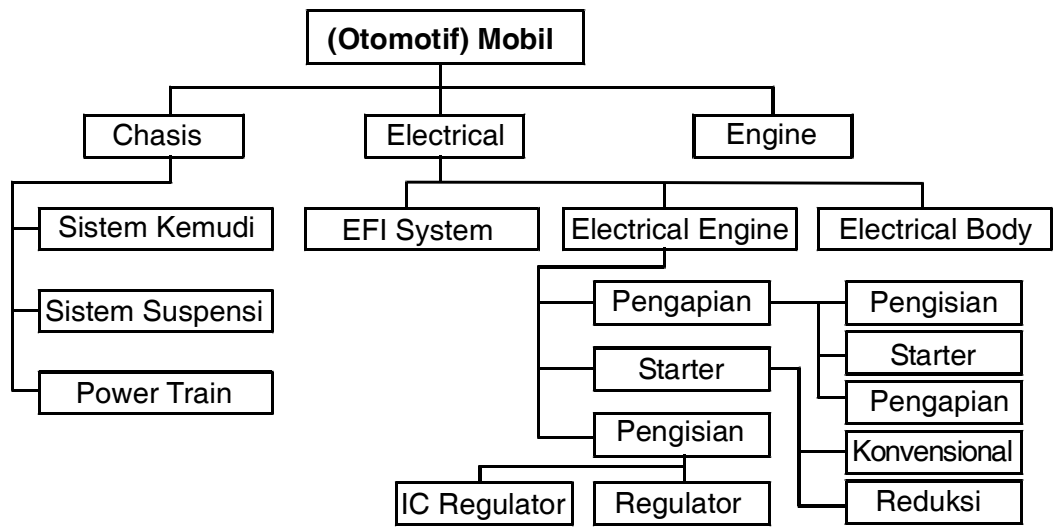

Gambar contoh peta materi Otomotif. Masing-masing kotak masih dapat dibagi lagi, sehingga sampai ke ranting terkecil.

Peta materi berguna bagi kita untuk melihat cakupan dan cukupan (keluasan dan kedalaman) materi. Dengan peta materi kita dapat menentukan seberapa luas atau mencakup apa saja materi yang akan dibahas, dan seberapa mendalam pembahasan akan kita lakukan. Semakin detil kita kembangkan ranting peta materi maka semakin dalam bahasan materi kita. Pada contoh di atas, materi diperdalam pada ranting electrical engine.

Setelah peta materi selesai, maka materi tersebut dapat anda tuangkan ke dalam format GBIM yang dapat dibuat dalam bentuk matrik sebagai berikut. 


\section{Contoh GBIM untuk SPM}

Mata Pelajaran

Topik

Jenjang/KIs/Semester

Penulis

Standard kompetensi

Kompetensi Dasar

\begin{tabular}{|c|c|c|c|c|c|c|c|c|}
\hline \multirow[b]{2}{*}{ No } & \multirow[b]{2}{*}{ Indikator } & \multirow[b]{2}{*}{$\begin{array}{l}\text { Pokok } \\
\text { Materi }\end{array}$} & \multirow[b]{2}{*}{ Evaluasi } & \multicolumn{4}{|c|}{ Media } & \multirow[b]{2}{*}{ Sumber } \\
\hline & & & & $\begin{array}{l}\text { Text/ } \\
\text { Narasi }\end{array}$ & Audio & \begin{tabular}{|c|} 
Video/ \\
Animasi
\end{tabular} & Simulasi & \\
\hline & & & & & & & & \\
\hline & & & & & & & & \\
\hline & & & & & & & & \\
\hline & & & & & & & & \\
\hline & & & & & & & & \\
\hline & & & & & & & & \\
\hline
\end{tabular}

Format GBIM dapat berbeda-beda sesuai dengan kebutuhan. Yang terpenting format ini harus dapat menjadi pedoman dalam penulisan naskah.

\section{Penulisan naskah}

Berdasarkan GBIM yang telah anda susun, anda dapat menulis naskah media MPI. Naskah merupakan cetak biru untuk media yang akan anda buat. Selain berisi materi, naskah berisi petunjuk-petunjuk teknis untuk pemrograman, penyediaan gambar, suara, animasi, simulasi, dll. Naskah MPI biasanya lebih rumit daripada naskah buku atau makalah. Dikatakan lebih rumit, karena pada naskah MPI, anda harus memikirkan sekaligus aspek pembelajaran, materi, interaktivitas, serta petunjuk teknis, dll. 
Penulisan naskah yang baik akan sangat membantu dalam pelaksanaan pembuatan media selanjutnya. Penulisan naskah dimulai dengan membuat diagram alur atau flowchart. Sebagaimana namanya, diagram ini menunjukkan alur sajian program. Alur sajian program merupakan rekayasa pembelajaran, artinya pada penyusunan flowchart ini anda sedang menggiring dan mengarahkan siswa mencapai tujuan pembelajaran yang dikehendaki. Flowchart bisa linear, bercabang, ataupun gabungan.

\section{Contoh flowchart linear}

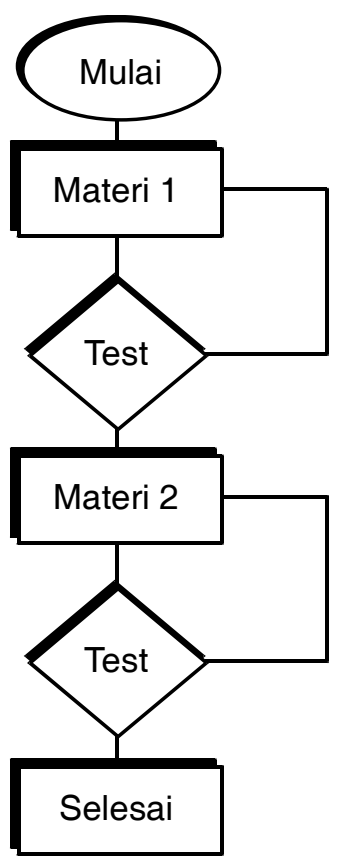




\section{Contoh flowchart branching}

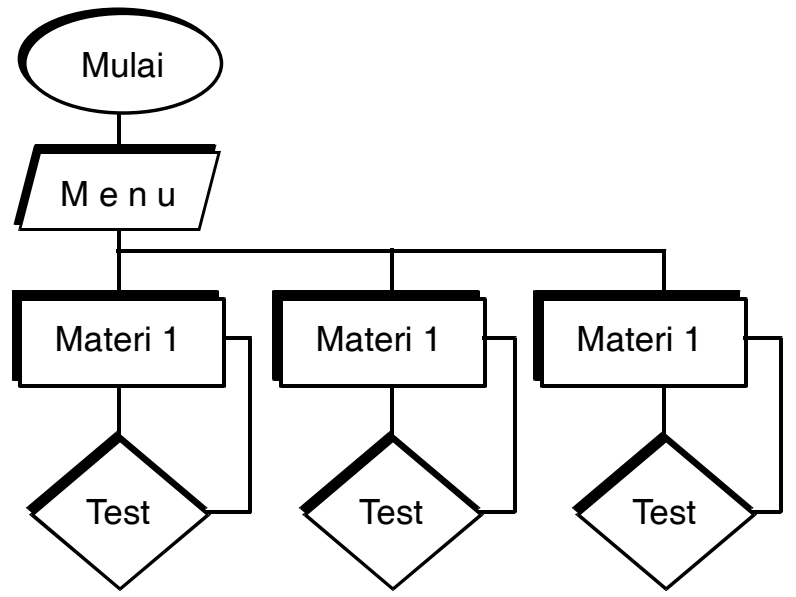

Setelah anda membuat flowchart, maka langkah selanjutnya adalah menulis naskah. Sebagaimana telah disebutkan di atas bahwa naskah merupakan petunjuk-petunjuk bagi pelaksana produksi seperti programer, grafis, animasi, narasi, dll. Maka format naskah harus mengandung semua elemen petunjuk tersebut. Ada berbagai format naskah yang dapat anda kembangkan sesuai dengan kebutuhan. Berikut ini adalah salah satu contoh format naskah MPI 
Mata Pelajaran

Judul/Topik

Kelas/Semester

\begin{tabular}{|c|c|}
\hline Nama Frame: . & Hal: ....... \\
\hline Tampilan: & Sound/Narasi: \\
\hline $\begin{array}{l}\text { Kolom ini berisi seluruh materi yang akan } \\
\text { tampil di layar, baik teks, gambar, animsi, } \\
\text { tombol navigasi, dll. }\end{array}$ & $\begin{array}{l}\text { Kolom ini } \\
\text { berisi teks } \\
\text { yang akan } \\
\text { dibacakan/ } \\
\text { narasi atau } \\
\text { pun suara } \\
\text { lainnya }\end{array}$ \\
\hline \multicolumn{2}{|c|}{$\begin{array}{l}\text { Keterangan/Petunjuk: } \\
\text { Kolom ini berisi keterangan tampilan, petunjuk } \\
\text { pemrograman, petunjuk gambar, animasi, simulasi, dll }\end{array}$} \\
\hline
\end{tabular}

Ketika anda menuliskan materi sajian pada kolom tampilan dan narasi, usahakan anda menempatkan diri sebagai murid atau user. Pertimbangkanlah apakah sajian menarik bagi user, mudah dipahami, memberikan motivasi, dll. Sedangkan ketika anda mengisi kolom keterangan buatlah keterangan atau petunjuk yang sejelas-jelasnya, anggaplah bahwa naskah ini akan diproduksi oleh orang lain.

Apabila naskah sudah selesai, ada baiknya anda konsultasikan dengan sejawat atau siswa anda, mungkin mereka dapat memberikan masukan. Seringkali kita menjumpai bahwa sudut pandang oranglain merupakan masukan yang penting yang mungkin tidak terpikirkan oleh kita sebelumnya. 


\section{Laksanakan pembuatan media}

Setelah menyelesaikan naskah, kita dapat langsung pada kegiatan produksi. Kegiatan produksi mencakup pembuatan rancangan tampilan, pemrograman, pembuatan gambar/grafis, pembuatan animasi, pemotretan, pengetikan teks, pengisian suara, pengisian musik, dll. Pelaksanaan produksi biasanya dilakukan oleh satu tim kerabat kerja sesuai dengan keahlian dan kemampuan masing-masing.

Apabila naskah ditulis oleh orang lain, ada baiknya sebelum memulai produksi dilakukan script conference. Script conference adalah pertemuan antara penulis naskah dengan produser dan kerabat kerja produksi untuk membahas segala sesuatu yang berkaitan dengan naskah baik pengembangan ide, konfirmasi materi, masalah-masalah teknis, sumber bahan, dll.

Langkah-langkah kegiatan produksi dapat digambarkan sebagai berikut.

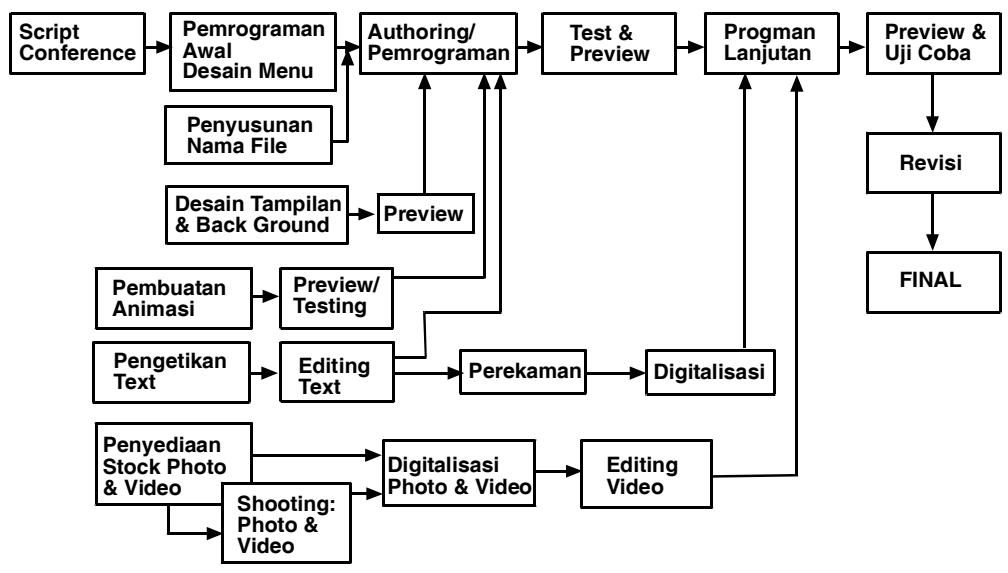

Pemrograman awal atau pemrograman dasar dapat dilakukan simultan dengan penyusunan nama file, pembuatan desain tampilan, serta penyediaan stock media seperti foto, video, gambar, dll. Sementara itu rekaman suara sebaiknya dilakukan setelah editing 
teks dan gambar untuk menghindari terjadinya pengulangan rekaman suara. Setelah pemrograman cukup lengkap, lakukanlah test dan preview. Test dan preview sebaiknya dilakukan oleh orang lain agar kita mendapat masukan. Berdasarkan masukan tersebut, dilakukan revisi dan pemrograman dilanjutkan. Preview dan revisi dapat dilakukan berulang-ulang sesuai dengan kebutuhan sampai dengan anda merasa puas dengan produk yang dihasilkan.

\section{Evalusi dan Revisi}

Evaluasi pada kegiatan produksi ini disebut evaluasi formatif, yakni evaluasi yang bertujuan untuk memperbaiki produk. Evaluasi dapat dilakukan dengan beberapa cara, antara lain test, preview, dan uji coba. Revisi adalah tindakan perbaikan berdasarkan hasil evaluasi.

Test bertujuan untuk menemukan dan memperbaiki kesalahan, kekurangan ataupun kelemahan produk yang sedang kita buat. Ada beberapa jenis test dalam pembuatan media, antara lain test fungsi, test kehandalan, dan test kompatibilitas. Test fungsi dimaksudkan untuk menguji apakah fungsi-fungsi tombol interaktivitas telah berfungsi dengan baik atau tidak. Test kehandalan untuk menguji kemampuan dan kecepatan software merespon berbagai kemungkinan klik oleh user serta keamanan sistem. Sedangkan test kompatibilias dimaksudkan untuk menguji kemungkinan software tersebut dijalankan pada berbagai sistem operasi dan kapasitas komputer.

Preview adalah proses melihat awal sebelum produk dipublikasikan. Preview biasanya dilakukan oleh tim ahli dan produser untuk melihat apakah produk sudah memenuhi syarat ataukah masih ada bagianbagian yang harus diperbaiki.

Sedangkan uji coba merupakan evaluasi yang dilaksanakan setelah produk dianggap selesai. Uji coba bertujuan untuk mendapatkan masukan dari calon user. Uji coba dapat dilakukan secara perseorangan, kelompok kecil, ataupun kelas. 


\section{Pengemasan}

Setelah semuanya selesai, anda tinggal memberi sentuhan akhir berupa pemaketan, pembuatan kemasan, petunjuk pemanfaatan, ataupun bahan penyerta untuk siswa. Agar produk anda kelihatan menarik, buatlah desain cover dan kemasan yang baik. Selamat mencoba.

\section{BAHAN PUSTAKA}

Gagne, Robert M., Leslie J. Briggs, Walter W. Wager, Principles of Instructional Design, Harcout Brace Jovanovich College, 1992

Hannafian, Michael J. and Kyle L. Peck, The Design, Development, and Evaluation of Instructional Sofware, Macmillan Pub. Com., New York, 1988

Harun, Jamaluddin, Asas Multimedia dan Aplikasinya dalam

Pembelajaran, Centre for Teaching and Learning, Universiti Teknologi Malaysia

Kusnandar, Evaluasi Program Multimedia Pembelajaran, Pustekkom, 2000

Purwanto, Dasar-dasar Pengembangan Multimedia, Pustekkom, 2000

Purwanto, Hardjito, Kusnandar, Multimedia Interaktif, Jejak Langkah

Teknologi Pendidikan, Pustekkom, 2006

Romiszowski, A.J., Developing Auto-Instructional Materials, Kogan

Page, New York, 1992 